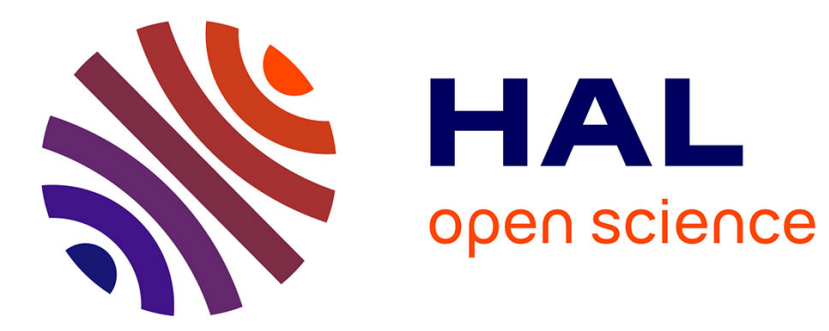

\title{
Biocatalysed Synthesis of Chiral Amines: Continuous Colorimetric Assays for Mining Amine-Transaminases
}

Léa Gourbeyre, Egon Heuson, Franck Charmantray, Virgil Hélaine, Adrien Debard, Jean-Louis Petit, Véronique de Berardinis, Thierry Gefflaut

\section{- To cite this version:}

Léa Gourbeyre, Egon Heuson, Franck Charmantray, Virgil Hélaine, Adrien Debard, et al.. Biocatalysed Synthesis of Chiral Amines: Continuous Colorimetric Assays for Mining Amine-Transaminases. Catalysis Science \& Technology, 2021, 11 (3), pp.904-911. 10.1039/D0CY02070B . hal-03191963

\section{HAL Id: hal-03191963 https://hal.science/hal-03191963}

Submitted on 7 Apr 2021

HAL is a multi-disciplinary open access archive for the deposit and dissemination of scientific research documents, whether they are published or not. The documents may come from teaching and research institutions in France or abroad, or from public or private research centers.
L'archive ouverte pluridisciplinaire HAL, est destinée au dépôt et à la diffusion de documents scientifiques de niveau recherche, publiés ou non, émanant des établissements d'enseignement et de recherche français ou étrangers, des laboratoires publics ou privés. 


\section{Biocatalysed Synthesis of Chiral Amines: Continuous Colorimetric Assays for Mining Amine-Transaminases}

Léa Gourbeyre, ${ }^{a}$ Egon Heuson, ${ }^{a}$ Franck Charmantray, ${ }^{a}$ Virgil Hélaine,, Adrien Debard, ${ }^{\mathrm{b}}$ Jean-Louis Petit, ${ }^{\mathrm{b}}$ Véronique de Berardinis, ${ }^{b}$ and Thierry Gefflaut ${ }^{a *}$

In the course of our research aimed at the design of new biocatalytic processes for the enantioselective synthesis of chiral amines, we have developed new continuous assays for the screening of amine-transaminases collections. These assays are based on the use of hypotaurine as irreversible amino donor. This $\beta$-aminosulfinic acid is converted upon transamination into 2-oxoethylsulfinic acid, which instantaneously decomposes into acetaldehyde and sulfite ions that can be easily detected by spectrophotometry using Ellman's reagent. Two complementary assays were developed based on this titration method. Firstly, a direct assay allowed detecting various transaminases able to use hypotaurine as amino donor. In a second coupled assay, L-alanine is used as generic donor substrate of aminetransaminases and is regenerated using an auxiliary hypotaurine-transaminase. The powerful and complementary nature of both assays was demonstrated through the screening of a collection of 549 amine-transaminases from biodiversity, thus allowing the discovery of a variety of valuable new biocatalysts for use in synthetic processes.

\section{Introduction}

Transaminases (TA, E.C. 2.6.1.X) which offer a highly stereoselective access to chiral amino pharmaceuticals and bioactive compounds have gained considerable interest in the past two decades. ${ }^{1-3}$ TA are pyridoxal phosphate (PLP)-dependent enzymes catalyzing the reversible transfer of the amino group from an amine donor substrate onto a carbonyle acceptor substrate. TA belong to fold-types I and IV of the large family of enzymes using PLP for catalyzing a variety of chemical reactions. ${ }^{4-5}$ The TA family is further divided into 6 classes based on sequence homology and related substrate spectra. Furthermore, TA are classically divided into 2 groups: $\alpha$-TA which are exclusively active with $\alpha$-amino and $\alpha$-keto acids and amine-TA (also called $\omega$ TA) which are able to accept other carbonyle and amino compounds as substrates. Most amine-TA belong to class III (fold-type I), although some of them have been found in class IV (fold-type IV) displaying an unusual stereoselectivity $((R)$-amine-TA $) .{ }^{6}$ The use of TA for chiral amine synthesis brings many benefits including broad application scope, high stereoselectivity and no need for auxiliary cofactor recycling. However, a major drawback of transamination lies in its reversible nature and therefore, an equilibriumshift strategy is almost always needed. ${ }^{7-8}$ A simple and efficient solution is to use cheap isopropylamine (IPA) as amine donor since acetone, which is formed from IPA upon transamination, can be easily removed from the reaction medium. ${ }^{9-11}$ Unfortunately, IPA is not a common substrate for amine-TA. An alternative frequently used method is the addition of an auxiliary enzyme to catalyse a thermodynamically favored transformation of the carbonyle co-product formed from the amine donor substrate. ${ }^{12-14}$ In some cases, a spontaneous transformation of the co-product formed from a smart amine donor can afford the needed equilibrium shift. This includes cyclisation of amino or amido carbonyle derivatives formed from diamino or dicarbonyle compounds, ${ }^{15-22}$ or decomposition of $\beta$-keto acids. ${ }^{23-24}$ Following this last approach, we used Lcysteine sulfinic acid (L-CSA) as irreversible amine donor in AspTA-catalyzed syntheses of a variety of glutamic acid analogues. ${ }^{25-26}$ L-CSA is converted upon transamination into an unstable $\beta$-keto sulfinic acid which spontaneously releases sulfur dioxide. In addition to the equilibrium shift, this chemical transformation also affords an efficient way of measuring enzyme activity. Indeed, $\mathrm{SO}_{2}$ is hydrated into sulfite ions and easily titrated by colorimetry using Ellman's reagent (5,5'-dithiobis-(2-nitro-benzoic acid), DTNB). ${ }^{27-28}$ Therefore this methodology was used to develop highly efficient high throughput screening assays for exploring $\alpha$-TA collections. ${ }^{29}$ Regarding the widespread application of amine-TA, the design of continuous and high throughput screening assays suitable for this group of enzymes is of utmost importance for identifying new biocatalysts in large collections of wild-type or mutant enzymes. Therefore, various methods have been reported over the last years, and can be divided into two categories. The first one corresponds to the direct detection of one of the transamination products or of a spontaneously formed derivative. The second category involves a coupled reaction usually catalysed by an auxiliary enzyme. Hence, acetophenone or acetonaphtone formed from the corresponding aryl-alkylamines can be directly titrated by spectrophotometry or fluorometry, ${ }^{30-31}$ whereas o-xylylenediamine or $p$-nitrophenylethylamine used as amino donor results in the formation of polymerized colored derivatives. ${ }^{17,32}$ Despite their simplicity, these methods are however limited to enzymes able to use these particular amine donors and formation of precipitated polymers can impair the development of continuous assays. Alternatively, several coupled-assays are based on auxiliary redox reactions. 


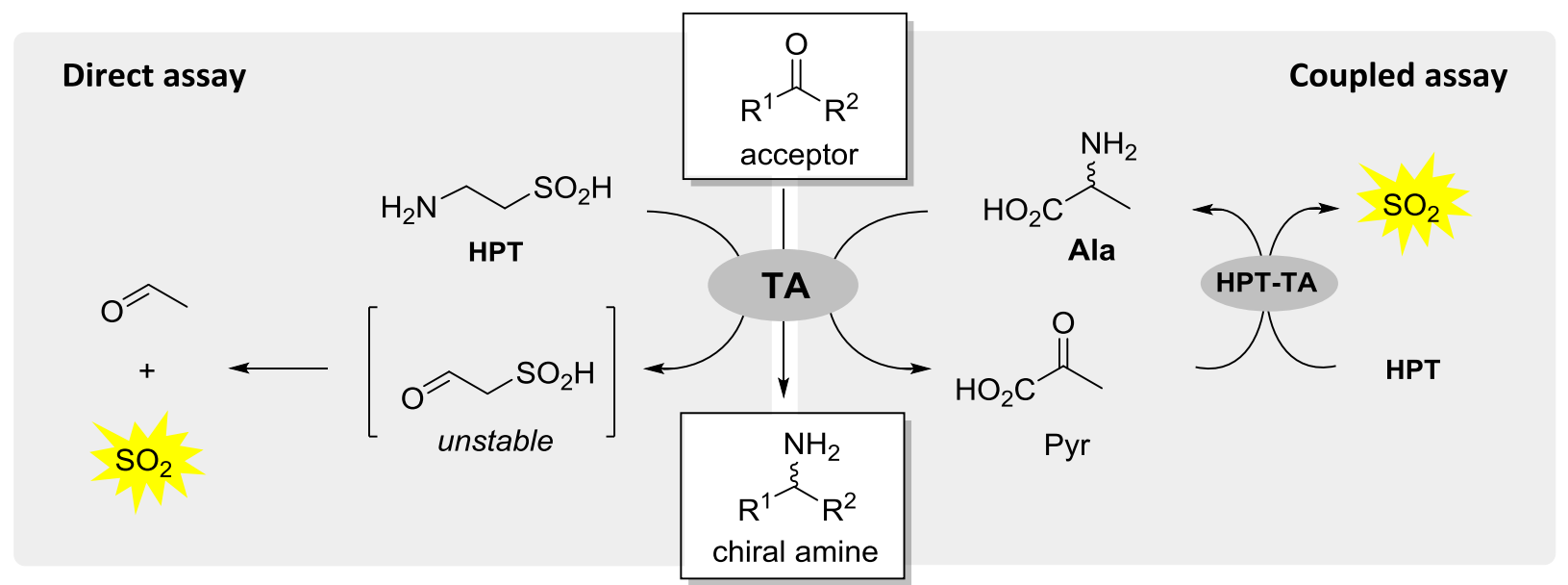

Figure 1. Principle of direct and coupled screening assays.

For example, pyruvic acid (Pyr) formed from alanine (Ala), a preferred substrate for most known amine-TA, was reduced to lactic acid and a $\mathrm{pH}$ indicator was used to monitor consecutive $\mathrm{pH}$ decrease. ${ }^{33}$ Alternatively, L- or D-Ala produced from Pyr, was oxidised using auxiliary L- or D-amino acid oxidases (AAO) converting $\mathrm{O}_{2}$ into $\mathrm{H}_{2} \mathrm{O}_{2}$ which was itself used to oxidise a chromogenic substrate using horse radish peroxidase as secondary auxiliary enzyme. ${ }^{34}$ However, this method was hindered by the limited availability of L-AAO for large scale screening processes. ${ }^{35}$ In order to circumvent this limitation, glyoxylic acid was used instead of Pyr as acceptor and glycine oxidase was used as auxiliary redox enzyme for producing $\mathrm{H}_{2} \mathrm{O}_{2}$ from achiral glycine. ${ }^{36}$ In another study, addition of an alanine-racemase as third auxiliary enzyme allowed conversion of L-Ala into D-Ala before oxidation by readily available D-AAO. ${ }^{37}$ However, this last screening method was not yet reported in a continuous version. Herein, we report the design and validation of new colorimetric and continuous assays based on the use of hypotaurine (HPT) as irreversible amino donor and on specific colorimetric titration of sulfite ions produced from HPT upon transamination. Two complementary assays were developed and used on cell lysates for the screening of a large collection of putative amine-TA from microbial diversity.

\section{Results and Discussion}

As shown in figure 1, two assays based on sulfite titration were developed. In the direct assay, HPT is used as unique amino donor substrate and leads upon transamination to the release of sulfur dioxide, itself instantaneously hydrated into sulfite ions which react with DTNB to give a colored thiolate anion $\left(\lambda=412 \mathrm{~nm}, \varepsilon=14150 \mathrm{M}^{-1} \mathrm{~cm}^{-1}\right)$. $^{27}$ In the coupled assay, Ala, is used as standard amine donor and is regenerated via an auxiliary transamination catalysed by an HPT-TA. This non-limiting coupled reaction thus allows the activity measurement through sulfite production and can afford an equilibrium shift.

\section{Direct assay performance and validation.}

In order to develop the direct assay, we chose the transamination between HPT and Pyr as a model reaction and $\omega$ TA from Caulobacter crescentus (Uniprot ID Q9A3Q9) as a model enzyme. This amine-TA was previously shown to be active with $\beta$-alanine, the carboxylic analogue of HPT. ${ }^{38}$ Therefore Q9A3Q9 was cloned and over-expressed in Escherichia coli with addition of a 6-histidine-tag (His-tag) in order to facilitate its purification. Although commercially available, HPT was readily prepared from cystamine on multigram scale, using a modified procedure reported for the synthesis of CSA from cystine $($ see $\mathrm{SI}) .{ }^{39}$ In this assay, regarding our previous results obtained with CSA and $\alpha-$ TA $^{29}$ we assumed that HPT should be quantitatively converted into sulfite upon transamination whereas sulfites would be efficiently titrated with DTNB in the presence of an amine-TA. In order to verify these assumptions and determine the dynamic range of measurable enzyme activities, various concentrations of purified Q9A3Q9 (0.03 - $7 \mu \mathrm{g} /$ well) were used with HPT (20 mM), Pyr (2 mM) and DTNB (1 mM). Under these conditions, a linear correlation was observed over the whole range of TA concentration (see figure S1), indicating that desulfination and production of the colored thiolate were not rate limiting. A specific activity of $0.54{\mathrm{U} . \mathrm{mg}^{-1}}$ was calculated for Q9A3Q9 with this couple of substrates. The limit of detection (LOD) of TA activity was found at $0.02 \mathrm{mU} /$ well (i.e. $0.02 \mathrm{nmol}$ of substrate converted per min and per well). Moreover, the maximum measurable activity was found at $16 \mathrm{mU} /$ well. This latter value corresponds to the absorbance saturation reached in the minimum time needed to measure a reliable activity under the experimental conditions used. Hence, this assay offers a dynamic range from 1 to 800 
which is very close to what was previously obtained with an $\alpha$-TA (Asp-TA) and CSA used as sulfinic amine donor. ${ }^{29}$ These results confirmed that HPT can behave as a smart amine donor for amine-TA, affording an equilibrium shift and a highly efficient colorimetric assay.

\section{Screening of an amine-TA collection with the direct assay.}

In order to identify a variety of amine-TA able to use HPT as amine donor, the direct assay was applied to the screening of a collection of 549 well over-expressed candidate amine-TA selected from biodiversity. The selection was done through a sequence driven approach by genome mining, using 60 known TA from class III as reference sequences (table S2). This collection was expected to be representative of the diversity of amine-TA from class III (see SI for the TA library construction). Experiments were performed on cell free extracts in 96-well microplates and Pyr was first used as standard acceptor. A reliable hit threshold (HT) was determined using a statistical approach with 32 independent cultures of $E$. coli host cells without overexpressed TA as negative control (see experimental section for detailed calculation of HT). Moreover, in order to take into account the presence of endogenous acceptors in $E$. coli lysates and a possible acceptor-independent desulfination of HPT, activity of each lysate was also measured in the absence of added acceptor (see $A_{0}$ in table 1). Only TA with activities superior to HT and to $4 * A_{0}$ were then considered as real hits.

Selected screening results are reported in table 1. Interestingly, low HT (0.051 mU/well) with HPT/Pyr couple of substrates, and low $A_{0}$ values measured with HPT alone allowed the highly sensitive detection of 64 TA able to use HPT as amine donor. The 20 best hits outlined in table 1 displayed activities above $0.5 \mathrm{mU} /$ well which should roughly

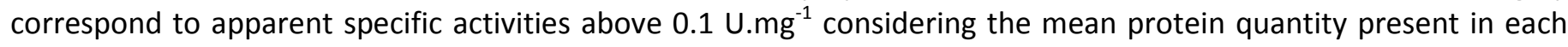
well $(5 \mu \mathrm{g})$. Moreover, it appeared that hits are distributed in distinct groups of enzymes, with various annotations and share low homologies (see figure S4 and S5). Results obtained with two other acceptors are also reported in table 1. Although butanal ( $\mathrm{PrCHO}$ ) was already reported to be a substrate of several amine-TA, 2-oxopentanoic acid (2OP) represented a more challenging substrate. Indeed, considering the commonly described general model of $(S)$ amine-TA active site, ${ }^{40}$ the propyl chain of $20 \mathrm{P}$ should be poorly accommodated in a small binding pocket where groups larger than methyl or ethyl are rarely tolerated.

Low HT values, determined for both substrates allowed the detection of 94 and 24 hits for PrCHO and 2OP respectively, which were all also active with Pyr as acceptor. With $\mathrm{PrCHO}$, the 20 best hits displayed activities from 0.12 to $1.04 \mathrm{mU} /$ well. In the case of 2OP, as anticipated, low activities were measured with only two hits over 0.1 $\mathrm{mU} /$ well. These two TA were also found among the 20 best hits detected with Pyr and PrCHO (table 1, entries 4 and 5). These results showed that the direct assay is suitable for the highly sensitive detection in cell lysates of amine-TA able to use HPT as amine donor and a variety of acceptor substrates.

\section{Coupled assay performance and validation.}

Because HPT is clearly not a standard amine donor for TA, and considering that Ala is a substrate of most amine-TA described to date, we designed the coupled assay in which Ala is used as primary amine donor and is regenerated using an auxiliary TA and HPT as secondary amine donor. First experiments with Q9A3Q9 used for direct assay development rapidly showed that this TA was neither active nor stable enough for use in large scale screening experiments. Therefore, an alternative auxiliary HPT-TA was searched among the hits from the first screening of our TA collection performed with the direct assay. Hence, four TA among the most active with Pyr and HPT, AOKEV7, Q48AP6, IOJLI1 and A9CV07 (table 1, entries 5, 11, 23 and 26) were recloned with addition of a His-tag, produced and purified for further characterisation. Specific activities of these TA were measured, using the direct assay, for a series of 21 acceptors and are reported in table 2. All of the four TA showed activities higher than $0.1 \mathrm{U} / \mathrm{mg}$ with short chain keto acids 1-4 with A9CV07 being the most active enzyme with Pyr 2 . A low activity $(<0.05 \mathrm{U} / \mathrm{mg})$ with keto acids 5-7 bearing side chains with more than 2 carbons was detected with AOKEV7 only. None of the TA showed detectable activity with branched or carboxylated keto acids 8-10, acetone $\mathbf{1 1}$ or acetophenone $\mathbf{1 2}$. A low activity $<$ $0.02 \mathrm{U} / \mathrm{mg}$ ) was observed with hydroxyacetone, dihydroxyacetone and formaldehyde 13-15 in the case of Q48AP6 and IOJLI1 whereas all other tested aldehydes 16-21 were shown to be substrates of Q48AP6, AOKEV7 and IOJLI1. Finally, A9CV07 was shown to display a low activity only with hydroxylated aldehydes $\mathbf{2 0}$ and $\mathbf{2 1}$. Therefore due to its good activity with Pyr and its narrow substrate spectrum, A9CV07 from Hoeflea phototrophica, appeared as the best candidate for use as auxiliary enzyme in the coupled assay. Satisfactorily, thermostability studies showed that this TA maintained $80 \%$ of its activity after $48 \mathrm{~h}$ at $30{ }^{\circ} \mathrm{C}$ (see Fig S2). Subsequently, the direct assay was used to accurately determine apparent Michaelis constants $(\mathrm{Km})$ and $k_{\text {cat }}$ for the transamination reaction between HPT and Pyr catalysed by A9CV07 (see Fig S3): $\mathrm{Km}_{\text {HPT }}=22.0 \pm 1.2 \mathrm{mM}, \mathrm{Km}_{\text {Pyr }}=0.25 \pm 0.03 \mathrm{mM}, k_{\text {cat }}=181 \pm 7 \mathrm{~min}^{-1}$. Having identified a suitable auxiliary TA, transamination between 2-oxoglutaric acid (2OG) and Ala was chosen as model reaction and a TA from Synechococcus sp. (Uniprot ID A0AOH3K2P4 previously referenced Q5N2G0) as a model TA. 
Table 1. Selected screening results from the direct assay with HPT as amine donor $\left(\mu_{c}, \sigma_{c}, \mathrm{HT}\right.$ and activities of 20 best hits ${ }^{[a]}$ in $\mathrm{mU} /$ well $=\mathrm{nmol}$ $\mathrm{SO}_{2}$ produced/min/well).

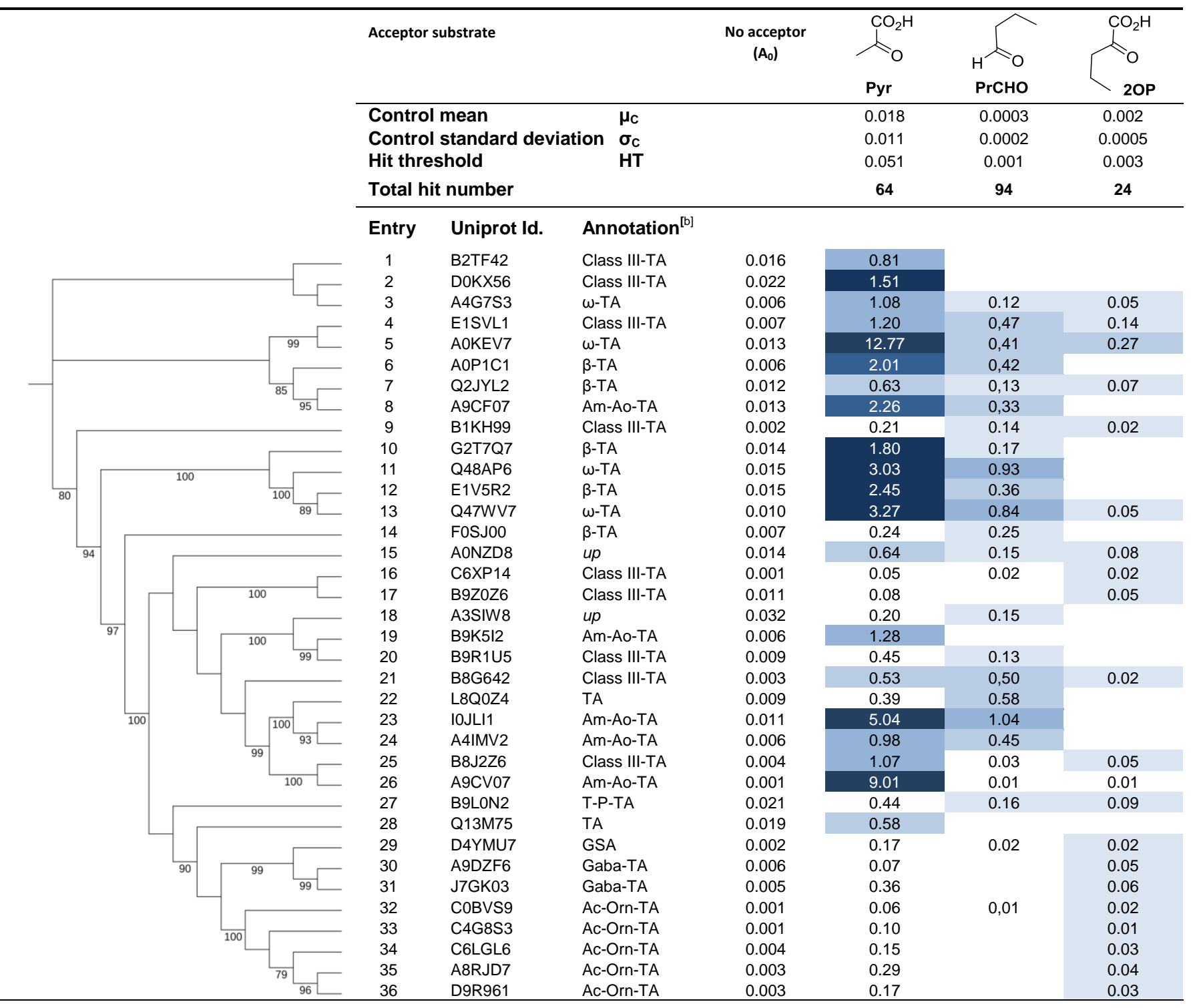

[a] The color gradient from light to dark blue underline the relative activity of the 20 best hits obtained with each carbonyle substrate. For each selected hit, activities detected with the other substrates are also given. ${ }^{[b]} \mathrm{GSA}=$ glutamate-1-semialdehyde aminomutase, $\omega$-TA $=\omega$-amino acid-pyruvate-transaminase, $\beta$-TA $=\beta$-alaninepyruvate-transaminase, Am-Ao-TA = adenosylmethionine-8-amino-7-oxononanoate-transaminase, up = uncharacterized protein, T-P-TA = taurine-pyruvatetransaminase, Ac-Orn-TA = acetylornithine-transaminase, Gaba-TA $=\gamma$-aminobutyrate-transaminase.

This enzyme was identified in previous screening experiments, ${ }^{29}$ and was found to display a good activity with Ala and $20 \mathrm{G}$ while being completely inactive with HPT as amine donor. A calibration curve was established in screening conditions, using various concentrations of model TA AOAOH3K2P4 (0.6 - $47 \mu \mathrm{g} /$ well), Ala (20 mM), HPT (10 mM), KG ( $2 \mathrm{mM})$, DTNB $(1 \mathrm{mM})$ and auxiliary TA A9CV07 $(6.7 \mu \mathrm{g}, 20 \mathrm{mU} /$ well). Under these conditions, as shown in figure 2, linearity was observed at least up to $1 \mathrm{mU} /$ well and an activity LOD of $0.05 \mathrm{mU} /$ well was calculated. A dynamic range from 1 to 20 was thus obtained in these conditions which were deemed suitable for large scale screening experiments.

\section{Screening of an amine-TA collection with the coupled assay.}

Representative results of the screening of our TA collection with the newly developed coupled assay are reported in table 3. As discussed above about the screening using the direct assay, hit thresholds were accurately determined through a series of control experiments without overexpressed TA or acceptor substrate.

In order to highlight the complementarity of both assays, we decided to use the same carbonyl derivatives, $\mathrm{PrCHO}$ and 2OP as acceptor substrates in the presence of Ala as primary amine donor. Most of the TA already found as hits using the direct assay were logically detected again with the coupled assay. Nevertheless, 18 TA displaying low activities with $2 \mathrm{OP}$ and HPT as unique donor ( $<0.1 \mathrm{mU} /$ well), were not detected with the coupled assay because of a higher HT $(0.132 \mathrm{mU} /$ well). This relatively high value likely results from the activity of host cells constitutive $\alpha$-TA able to use Ala and 2OP as substrate and justify the limited number of hits (15) detected with 2OP using the coupled assay. 
Table 2. Specific activities of selected TA (in U. $\mathrm{mg}^{-1}=\mu \mathrm{mol}$ of substrate converted per min and per mg of TA). ${ }^{\text {[a] }}$

\begin{tabular}{|c|c|c|c|c|c|c|}
\hline \multirow[t]{2}{*}{$a}$. & \multirow[t]{2}{*}{ eptor } & \multirow[t]{2}{*}{ HPT } & TA & + & + & \multirow[b]{2}{*}{ A9CV07 } \\
\hline & & & Q48AP6 & AOKEV7 & I0JLI1 & \\
\hline Acceptor & $\mathbf{R}^{1}$ & $\mathbf{R}^{2}$ & & & & \\
\hline 1 & $\mathrm{CO}_{2} \mathrm{H}$ & $\mathrm{H}$ & 1.38 & 1.83 & 0.89 & 1.69 \\
\hline 2 & $\mathrm{CO}_{2} \mathrm{H}$ & $\mathrm{Me}$ & 1.00 & 2.31 & 0.76 & 3.00 \\
\hline 3 & $\mathrm{CO}_{2} \mathrm{H}$ & $\mathrm{CH}_{2} \mathrm{OH}$ & 0.44 & 0.26 & 0.45 & 0.30 \\
\hline 4 & $\mathrm{CO}_{2} \mathrm{H}$ & Et & 0.10 & 0.17 & 0.22 & 0.65 \\
\hline 5 & $\mathrm{CO}_{2} \mathrm{H}$ & $\mathrm{Pr}$ & $<0.01$ & 0.02 & $<0.01$ & $<0.01$ \\
\hline 6 & $\mathrm{CO}_{2} \mathrm{H}$ & $\mathrm{Bu}$ & $<0.01$ & 0.04 & $<0.01$ & $<0.01$ \\
\hline 7 & $\mathrm{CO}_{2} \mathrm{H}$ & $\mathrm{CH}_{2} \mathrm{CH}_{2} \mathrm{SMe}$ & $<0.01$ & 0.02 & $<0.01$ & $<0.01$ \\
\hline 8 & $\mathrm{CO}_{2} \mathrm{H}$ & $\mathrm{iPr}$ & $<0.01$ & $<0.01$ & $<0.01$ & $<0.01$ \\
\hline 9 & $\mathrm{CO}_{2} \mathrm{H}$ & $\mathrm{iBu}$ & $<0.01$ & $<0.01$ & $<0.01$ & $<0.01$ \\
\hline 10 & $\mathrm{CO}_{2} \mathrm{H}$ & $\mathrm{CH}_{2} \mathrm{CH}_{2} \mathrm{CO}_{2} \mathrm{H}$ & $<0.01$ & $<0.01$ & $<0.01$ & $<0.01$ \\
\hline 11 & $\mathrm{Me}$ & $\mathrm{Me}$ & $<0.01$ & $<0.01$ & $<0.01$ & $<0.01$ \\
\hline 12 & $\mathrm{Me}$ & $\mathrm{Ph}$ & $<0.01$ & $<0.01$ & $<0.01$ & $<0.01$ \\
\hline 13 & $\mathrm{Me}$ & $\mathrm{CH}_{2} \mathrm{OH}$ & 0.01 & $<0.01$ & 0.01 & $<0.01$ \\
\hline 14 & $\mathrm{CH}_{2} \mathrm{OH}$ & $\mathrm{CH}_{2} \mathrm{OH}$ & 0.02 & $<0.01$ & 0.02 & $<0.01$ \\
\hline 15 & $\mathrm{H}$ & $\mathrm{H}$ & 0.01 & $<0.01$ & 0.02 & $<0.01$ \\
\hline 16 & $\mathrm{H}$ & $\mathrm{Me}$ & 0.12 & 0.06 & 0.25 & $<0.01$ \\
\hline 17 & $\mathrm{H}$ & Et & 0.12 & 0.04 & 0.15 & $<0.01$ \\
\hline 18 & $\mathrm{H}$ & $\operatorname{Pr}$ & 0.12 & 0.03 & 0.14 & $<0.01$ \\
\hline 19 & $\mathrm{H}$ & $\mathrm{Ph}$ & 0.07 & 0.02 & 0.07 & $<0.01$ \\
\hline 20 & $\mathrm{H}$ & $\mathrm{CH}_{2} \mathrm{OH}$ & 0.24 & 0.14 & 0.35 & 0.04 \\
\hline 21 & $\mathrm{H}$ & $\mathrm{CH}(\mathrm{OH}) \mathrm{CH}_{2} \mathrm{OH}$ & 0.08 & 0.02 & 0.06 & 0.01 \\
\hline
\end{tabular}

${ }^{\text {[a] }}$ Reaction conditions: acceptor (2 mM), HPT (10 mM), PLP (0.1 mM), DTNB (1 mM), TA (1-80 $\left.\mu \mathrm{g} / \mathrm{mL}\right)$, DMSO (5\%), potassium phosphate buffer (50 mM, pH 7.5)

Although close activities were often measured with both assays, (see for example entries 15, 16 and 22 with PrCHO and entries 17 and 18 with 2OP), higher values were measured with the coupled assay in several cases (see for example entries 5,10 and 23 with PrCHO and entry 6 with 2OP) indicating that Ala is a better donor than HPT for these particular TA. More interestingly, and as expected, many hits were exclusively detected with the coupled assay and correspond to enzymes inactive with HPT but accepting Ala as amine donor. Hence, 10 out of the 20 best hits with $\mathrm{PrCHO}$ and 9 out of the 15 hits with 2OP were detected only with the coupled assay. Moreover, for both acceptors, the coupled assay allowed the detection of TA displaying higher activities and therefore offering the best opportunities for synthetic applications. Finally, as outlined for the direct assay, the newly identified amine-TA showed broad diversity (see figure S4 and S5) and constitute an unprecedented set of biocatalysts with high synthetic potential for the highly stereoselective synthesis of chiral amines.

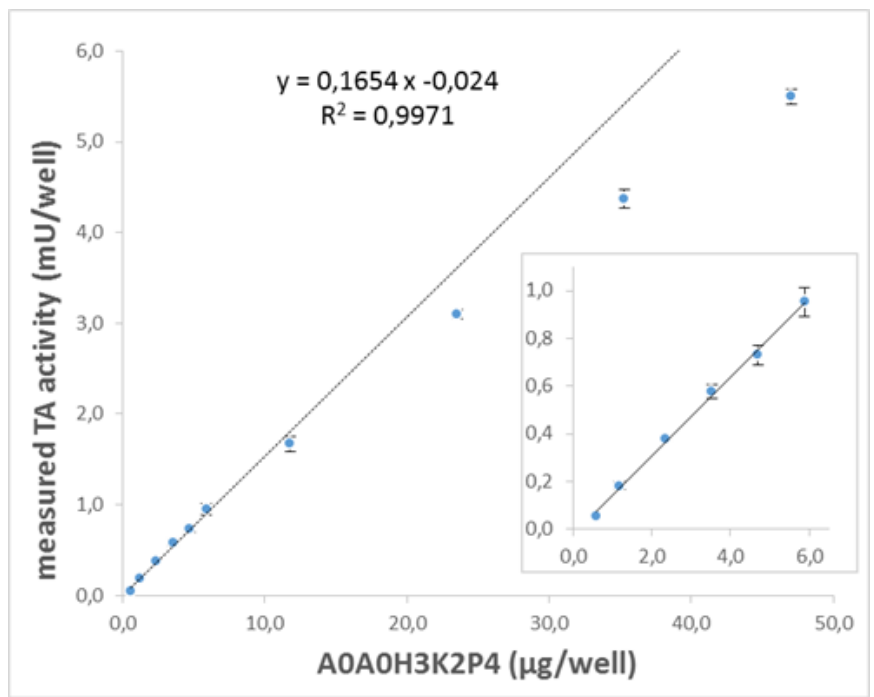

Figure 2. Calibration curve oft he model TA with the coupled assay 
Table 3. Selected screening results from the coupled assay with L-Ala as primary amine donor $\left(\mu_{c}, \sigma_{c}, H T\right.$ and activities of the 20 best hits ${ }^{[a]}$ in $\mathrm{nmol} \mathrm{SO} \mathrm{S}_{2}$ produced/min/well).

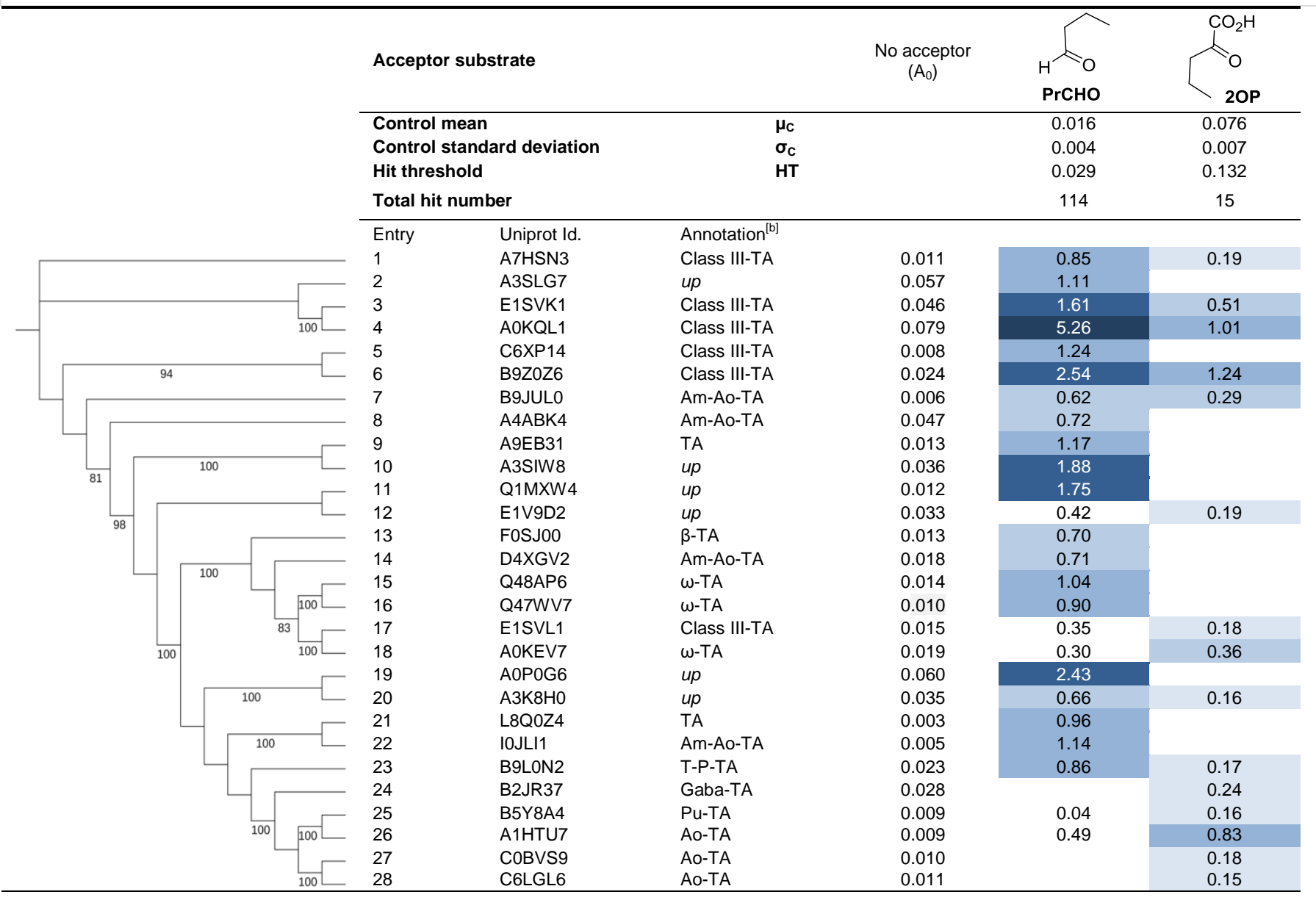

[a] The color gradient from light to dark blue underline the relative activity of the 20 best hits obtained with each substrate. For each selected hit, activities detected with other substrates are also given. ${ }^{[b]} \omega$-TA $=\omega$-amino acid-pyruvate-transaminase, $\beta$-TA $=\beta$-alanine-pyruvate-transaminase, Am-Ao-TA $=$ adenosylmethionine- 8 -amino-7-oxononanoatetransaminase, $u p=$ uncharacterized protein, $\mathrm{T}-\mathrm{P}-\mathrm{TA}=$ taurine-pyruvate-transaminase, $\mathrm{Ao}-\mathrm{TA}=$ acetylornithine-transaminase, $\mathrm{Pu}-\mathrm{TA}=$ putrescine-aminotransferase, $\mathrm{GABA}-\mathrm{TA}=\gamma-$ aminobutyrate-transaminase.

\section{Experimental Section}

Screening of the TA library. All reactions assays were performed at $30^{\circ} \mathrm{C}$, in $50 \mathrm{mM}$ potassium phosphate buffer, $\mathrm{pH}$ 7.5, in 96-well microplates and in a total volume of $200 \mu \mathrm{L}$. The direct assay was implemented using $10 \mathrm{mM} \mathrm{HPT}, 2$ $\mathrm{mM}$ carbonyle acceptor, $0.05 \mathrm{mM}$ PLP, $1 \mathrm{mM}$ DTNB, $1 \% \mathrm{EtOH}$, and $5 \mu \mathrm{L}$ of cell lysate from the TA library. The coupled assay was implemented using $20 \mathrm{mM}$ L-Ala, $10 \mathrm{mM}$ HPT, $2 \mathrm{mM}$ acceptor, $0.05 \mathrm{mM}$ PLP, $1 \mathrm{mM}$ DTNB, 1 \% EtOH, 20 $\mathrm{mU} /$ well A9CV07 $(6,7 \mu \mathrm{g})$, and $5 \mu \mathrm{L}$ of cell lysate from the TA library. Lysates from 32 independent cultures of E.coli cells bearing an empty plasmid were used in the same conditions as negative control for all type of assays. These control experiments allowed to calculate means $\left(\mu_{c}\right)$, standard deviations $\left(\sigma_{c}\right)$ and hit threshold $\left(H T=\mu_{c}+3^{*} \sigma_{c}\right.$ or HT $=1,75^{*} \mu_{\mathrm{c}}$ if $\sigma_{\mathrm{c}}<0.25^{*} \mu_{\mathrm{c}}$ ) for each set of substrates. ${ }^{29}$ Another control experiment was performed for both direct and coupled assays and for each enzyme of the library in the same conditions but without any acceptor substrate $\left(A_{0}\right)$. Plates were stirred $90 \mathrm{~s}$ before absorbance variations were recorded at $412 \mathrm{~nm}$ over $30 \mathrm{~min}$. TA activities were calculated using $\varepsilon=14150 \mathrm{M}^{-1} \cdot \mathrm{cm}^{-1}$ for the thiolate anion formed from DTNB. TA with activities above both HT and $4 * A_{0}$ were considered as hits.

\section{Conclusions}

We have developed two new continuous colorimetric assays suitable for screening amine-TA collections. Both assays, implemented on crude cell lysates, displayed high sensitivity and broad dynamic range. The direct assay allowed the identification of a series of highly active HPT-TA, among which an enzyme with a narrow substrate spectrum proved suitable for use as the auxiliary enzyme in the coupled assay. The latter was proven useful for the reliable TA activity measurement with L-Ala as standard amine donor and various carbonyl acceptors. Moreover, the coupled assay can obviously be implemented in a stereoselective fashion by using L- or D-Ala as amine donor in order to distinguish $(S)$ - or $(R)$-amine-TA. Finally the transamination reaction in both assays is the conversion of interest in asymmetric synthesis, i.e. the enantioselective formation of a chiral amine from a prochiral ketone, thus giving a reliable prediction of the TA applicability in biocatalytic processes. 


\section{Acknowledgements}

We thank the French National Center for Scientific Research (CNRS) and University of Clermont-Auvergne for financial support. We also thank Ms Martine Sancelme for enzyme production and Ms Virginie Pellouin for technical assistance.

\section{Notes and references}

1 E. E. Ferrandi and D. Monti, World J. Microbiol. Biotechnol., 2017, 34, 13.

2 A. Gomm and E. O'Reilly, Curr. Opin. Chem. Biol., 2018, 43, 106.

3 M. D. Patil, G. Grogan, A. Bommarius and H. Yun, Catalysts, 2018, 8, 254.

4 F. Steffen-Munsberg, C. Vickers, H. Kohls, H. Land, H. Mallin, A. Nobili, L. Skalden, T. van den Bergh, H.-J. Joosten, P. Berglund, et al., Biotechnology Advances, 2015, 33, 566.

5 N. V. Grishin, M. A. Phillips and E. J. Goldsmith, Protein Science, 1995, 4, 1291.

6 M. Höhne, S. Schätzle, H. Jochens, K. Robins and U. T. Bornscheuer, Nat. Chem. Biol., 2010, 6, 807.

7 P. Tufvesson, J. Lima-Ramos, J. S. Jensen, N. Al-Haque, W. Neto and J. M. Woodley, Biotechnol. Bioeng., $2011,108,1479$.

8 R. J. Meier, M. T. Gundersen, J. M. Woodley and M. Schürmann, ChemCatChem, 2015, 7, 2594.

9 C. K. Savile, J. M. Janey, E. C. Mundorff, J. C. Moore, S. Tam, W. R. Jarvis, J. C. Colbeck, A. Krebber, F. J. Fleitz, J. Bra nds, et al., Science, 2010, 329, 305.

10 E.-S. Park, J.-Y. Dong and J.-S. Shin, Org. Biomol. Chem., 2013, 11, 6929.

11 G. Matcham, M. Bhatia, W. Lang, C. Lewis, R. Nelson, A. Wang and W. Wu, CHIMIA, 1999, 53, 584.

12 F. G. Mutti, C. S. Fuchs, D. Pressnitz, J. H. Sattler and W. Kroutil, Adv. Synth. Catal., 2011, 353, 3227.

13 M. D. Truppo and N. J. Turner, Org. Biomol. Chem., 2010, 8, 1280.

14 S. Schätzle, F. Steffen-Munsberg, A. Thontowi, M. Höhne, K. Robins and U. T. Bornscheuer, Adv. Synth. Catal., 2011, $353,2439$.

15 H.-H. Lo, S.-K. Hsu, W.-D. Lin, N.-L. Chan and W.-H. Hsu, Biotechnol. Progress, 2005, 21, 411.

16 T. Li, A. B. Kootstra and I. G. Fotheringham, Org. Process Res. Dev., 2002, 6, 533.

17 A. P. Green, N. J. Turner and E. O'Reilly, Angew. Chem. Int. Ed., 2014, 53, 10714.

18 L. Martínez-Montero, V. Gotor, V. Gotor-Fernández and I. Lavandera, Adv. Synth. Catal., 2016, 358, 1618.

19 A. Gomm, W. Lewis, A. P. Green and E. O'Reilly, Chem. Eur. J., 2016, 22, 12692.

20 I. Slabu, J. L. Galman, N. J. Weise, R. C. Lloyd and N. J. Turner, ChemCatChem, 2016, 8, 1038.

21 R. C. Simon, F. Zepeck and W. Kroutil, Chem. Eur. J., 2013, 19, 2859.

22 E. Heuson, F. Charmantray, J.-L. Petit, V. de Berardinis and T. Gefflaut, Adv. Synth. Catal., 2019, 361, 778.

23 N. W. Fadnavis, S.-H. Seo, J.-H. Seo and B.-G. Kim, Tetrahedron: Asymmetry, 2006, 17, 2199.

24 J. D. Rozzell, US4518692 (A), May 21, 1985.

25 T. Gefflaut, Z. Assaf and M. Sancelme, Methods Mol. Biol., (Clifton, N.J.) 2012, 794, 55.

26 T. H. V. Huynh, M. N. Erichsen, A. S. Tora, C. Goudet, E. Sagot, Z. Assaf, C. Thomsen, R. Brodbeck, T. B. Stensbøl, W. E. BjørnYoshimoto, et al., J. Med. Chem., 2016, 59, 914

27 R. E. Humphrey, M. H. Ward and W. Hinze, Anal. Chem., 1970, 42, 698.

28 G. L. Ellman, Arch. Biochem. Biophys., 1959, 82, 70.

29 E. Heuson, J.-L. Petit, A. Debard, A. Job, F. Charmantray, V. de Berardinis and T. Gefflaut, Appl. Microbiol. Biotechnol., 2016, 100, 397.

30 S. Schätzle, M. Höhne, E. Redestad, K. Robins and U. T. Bornscheuer, Anal. Chem., 2009, 81, 8244.

31 T. Scheidt, H. Land, M. Anderson, Y. Chen, P. Berglund, D. Yi and W.-D. Fessner, Adv. Synth. Catal., 2015, 357, 1721.

32 D. Baud, N. Ladkau, T. S. Moody, J. M. Ward and H. C. Hailes, Chem. Commun., 2015, 51, 17225.

33 M. D. Truppo, J. D. Rozzell, J. C. Moore and N. J. Turner, Org. Biomol. Chem., 2009, 7, 395.

34 J. Hopwood, M. D. Truppo, N. J. Turner and R. C. Lloyd, Chem. Commun., 2011, 47, 773.

35 L. Pollegioni, P. Motta and G. Molla, Appl. Microbiol. Biotechnol., 2013, 97, 9323.

36 M. S. Weiß, I. V. Pavlidis, C. Vickers, M. Höhne and U. T. Bornscheuer, Anal. Chem., 2014, 86, 11847.

37 S. C. Willies, J. L. Galman, I. Slabu and N. J. Turner, Phil. Trans. R. Soc. A, 2016, 374, 20150084.

38 B.-Y. Hwang, S.-H. Ko, H.-Y. Park, J.-H. Seo, B.-S. Lee and B.-G. Kim, J. Microbiol. Biotechnol., 2008, $18,48$.

39 R. Emilliozzi and L. Pichat, Bull. Soc. Chim. Fr., 1959, 1887.

40 F. Steffen-Munsberg, C. Vickers, A. Thontowi, S. Schätzle, T. Meinhardt, M. Svedendahl Humble, H. Land, P. Berglund, U. T. Bornscheuer and M. Höhne, ChemCatChem, 2013, 5, 154. 